\title{
Novel Anti-Angiogenic Activity in Rubus coreanus Miquel Water Extract Suppresses VEGF-Induced Angiogenesis
}

\author{
Eok-Cheon Kim, Hye Jin Kim and Tack-Joong Kim ${ }^{\dagger}$ \\ Division of Biological Science and Technology, Yonsei-Fraunhofer Medical Device Lab., \\ College of Science and Technology, Yonsei University, Wonju 220-710, Korea
}

\begin{abstract}
Vascular endothelial growth factor (VEGF) is a key factor involved in the induction of angiogenesis and has become an attractive target for anti-angiogenesis therapies. The purpose of this study was to elucidate the anti-angiogenic activity of Rubus coreanus Miquel water extract (RCME). Rubus coreanus Miquel has long been employed as a traditional medicine, and recent studies have demonstrated that it has measureable biological activities. Thus, we investigated for the first time the effect of RCME on angiogenesis and its underlying signaling pathways. The effects of RCME were tested on in vitro models of angiogenesis, namely, proliferation, migration, invasion and tube formation of human umbilical vein endothelial cells as well as an ex vivo model of vessel sprouting from the rat aorta in response to VEGF. We observed that VEGF-induced angiogenesis was strongly suppressed by RCME treatment compared to that of the control group. Moreover, we found that RCME inhibited VEGF-induced activation of matrix metalloproteinases and phosphorylation of extracellular signal-regulated kinase and $\mathrm{p} 38$, and also effectively inhibited phosphorylation of VEGF receptor 2. These results indicated that RCME inhibits angiogenesis by suppressing phosphorylation of the VEGF receptor and may be useful for the treatment of angiogenesis-dependent diseases such as cancer and diabetic retinopathy.
\end{abstract}

Key Words: Angiogenesis, Rubus coreanus Miquel, VEGF receptor phosphorylation

\section{INTRODUCTION}

Angiogenesis is the process by which new blood vessels are formed from pre-existing endothelium (Carmeliet, 2003; Dulak and Jozkowicz, 2003). Physiologically, angiogenesis does not typically occur except during developmental and repair processes; however, undesirable angiogenesis does occur in diverse unrelated pathological conditions such as diabetic retinopathy, inflammatory diseases and tumorigenesis (Folkman, 1995). Angiogenesis is driven by a

\footnotetext{
*Received: September 24, 2014 / Accepted: November 10, 2014

${ }^{\dagger}$ Corresponding author: Tack-Joong Kim. Division of Biological Science and Technology, Yonsei University, 1 Yonseidae-gil, Wonju, Gangwon-do 220-710, Korea.

Tel: +82-33-760-2242, Fax: +82-33-760-2183

e-mail: ktj@yonsei.ac.kr

(C) The Korean Society for Biomedical Laboratory Sciences. All rights reserved.
}

tightly regulated balance between pro-angiogenic and antiangiogenic regulators (Folkman, 1996), and is triggered by angiogenic growth factors such as vascular endothelial growth factor (VEGF) (Hanahan and Folkman, 1996), which in turn induce activation of VEGF receptor (VEGFR) and downstream signal pathways (Risau, 1995). VEGF and its receptor have been extensively studied in many solid tumors (Droller, 1998; Kitamura et al., 1998; Balbay et al., 1999; Kurebayashi et al., 1999; Shaheen et al., 1999; Yoshiji et al., 1999). KDR, also known as VEGFR2 and Flk-1, is the main human receptor responsible for VEGF activity in pathological vascular development, and the VEGF-KDR signaling pathway has been validated as a key target for the development of anti-angiogenic agents (Mustonen and Alitalo, 1995). Many natural products that inhibit angiogenesis are traditionally used in anticancer treatments. Natural products contain a variety of chemopreventive compounds that have 
been shown to suppress the development of malignancies (Rao et al., 1995; Lin et al., 1997). For example, the fruit of the black raspberry, Rubus coreanus Miquel, is well known as an important traditional Korea medicinal herb (Ko et al., 2008; Lee et al., 2011) and has been reported to have anti-inflammatory, anti-nociceptive, anti-gastropathic, antirheumatic and chemopreventive effects (Erdemoglu et al., 2003; Nam et al., 2006; Kim et al., 2012) However, the anti-angiogenic properties of Rubus coreanus Miquel water extract (RCME) and its underlying mechanisms have not been studied. In the present study, we investigated the effect of RCME on angiogenesis and its intracellular signal pathway using in vitro and ex vivo angiogenesis models. Our results show that RCME prevented angiogenesis by inhibiting phosphorylation of VEGFR2.

\section{MATERIAL AND METHODS}

\section{Preparation of Rubus coreanus Miquel water extract}

Rubus coreanus Miquel was harvested in Kochang and Jungeup (Korea). For sample preparation, the dried Rubus coreanus Miquel was extracted three times with $2 \mathrm{~L}$ of water for one day. The resulting extracts were then filtered through Whatman No. 1 paper, combined, and concentrated using a rotary evaporator (EYELAN-1000, Japan) at $40^{\circ} \mathrm{C}$. Finally, the dried RCME were obtained.

\section{Endothelial cell culture and animal maintenance}

Human umbilical vein endothelial cells (HUVECs) were purchased from ATCC. HUVECs were maintained in M199 medium (Invitrogen, Carlsbad, CA) containing 20\% (v/v) fetal bovine serum (FBS), $100 \mathrm{unit} / \mathrm{ml}$ penicillin, 100 $\mu \mathrm{g} / \mathrm{ml}$ streptomycin (Lonza Walkersville, Walkersville, MD), $3 \mathrm{ng} / \mathrm{ml}$ basic fibroblast growth factor (Upstate Biotechnology, Lake Placid, NY), and 5 unit $/ \mathrm{ml}$ heparin at $37^{\circ} \mathrm{C}$ in a humidified $5 \% \mathrm{CO}_{2}$ atmosphere. HUVECs were used between passages $4 \sim 8$ for all experiments. Sprague-Dawley rats (age, 7 weeks) were obtained from Orient Bio Inc. (Sungnam, Korea) and were maintained on standard chow and water ad libitum. This investigation was conducted in accordance with the "Guide for the Care and Use of Laboratory Animals" adopted by the United States National
Institutes of Health. The study protocols used in this study were reviewed and approved by the Ethic Committee, Institutional Animal Care and Use Committee (IACUC) of Yonsei University (Wonju, Korea).

\section{Endothelial cell viability assay}

Cell viability was evaluated using the 3-(4,5-dimethylthiazol-2-yl)-2,5-diphenyltetrazolium bromide (MTT) assay. Briefly, HUVECs $\left(5 \times 10^{4}\right.$ cells/well $)$ were first plated in 24-well plates and cultured overnight. Cells were then treated with 1 100 $\mu \mathrm{g} / \mathrm{ml} \mathrm{RCME}$ for $24 \mathrm{hr}$, after which the medium was replaced with fresh medium containing 0.5 $\mathrm{mg} / \mathrm{ml}$ MTT (USB Corporation, Cleveland, $\mathrm{OH}$ ) to allow cleavage of the tetrazolium ring by mitochondrial dehydrogenases and formation of blue formazan crystals. After $4 \mathrm{hr}$, the residual MTT was carefully removed, and the crystals were dissolved by incubation with DMSO for $30 \mathrm{~min}$. The plates were then shaken for $5 \mathrm{~min}$, and the absorbance at $595 \mathrm{~nm}$ was measured using a microplate reader (Molecular Devices, Sunnyvale, CA). The optical density of untreated cells represented $100 \%$ viability, and the background color formation of MTT with DMSO added to an empty plate represented $0 \%$ viability.

\section{Endothelial cell proliferation assay}

The effect of RCME on HUVEC proliferation in response to VEGF (PEPRO TECH, Rocky Hill, NJ) was examined. Briefly, cells were seeded at a density of $4 \times 10^{4}$ cells per well in 12-well plates, incubated for $24 \mathrm{hr}$, and then treated with various concentrations of RCME in the absence or presence of VEGF $(20 \mathrm{ng} / \mathrm{ml})$. After a $48 \mathrm{hr}$ incubation, cells were trypsinized and counted with a Luna ${ }^{\mathrm{TM}}$ Automated Cell counter (Logos Biosystems, Korea).

\section{Western blot analysis}

Cells were harvested and lysed with RIPA buffer containing 2 mM EDTA, $137 \mathrm{mM} \mathrm{NaCl}, 20 \mathrm{mM}$ Tris- $\mathrm{HCl}$ (pH 8.0), $1 \mathrm{mM}$ sodium vanadate, $10 \mathrm{mM} \mathrm{NaF}, 1 \mathrm{mM}$ PMSF, $1 \%$ Triton X-100, 10\% glycerol and a protease-inhibitor cocktail. The protein concentration of each sample was determined using a BCA protein assay kit (Pierce, Rockford, IL). Proteins were electrophoresed on sodium dodecyl 
sulfate-polyacrylamide electrophoresis gels and transferred to polyvinylidene fluoride membranes (Pall Corporation, East Hills, NY). The blocked membranes were then incubated with the indicated antibodies, and immunoreactive bands were visualized using a chemiluminescent substrate. Antibodies for VEGF receptor 2, phospho-VEGF receptor 2 (Tyr 1175), phospho-p44/42 MAP kinase (Thr 202/Tyr 204), p44/42 MAP kinase, phospho-p38 MAP kinase (Thr 180/Tyr 182) and p38 MAP kinase were obtained from Cell Signaling (Beverly, MA).

\section{Endothelial cell migration assay}

In vitro cell migration assays were performed using the Transwell assay system (24-wells, 8 - $\mu$ m pore size with polycarbonate membrane; Corning Costar, Cambridge, MA). Briefly, the lower surface of the filter was coated with 10 $\mu \mathrm{g}$ gelatin. Next, fresh M199 medium (1\% FBS) containing VEGF was placed in lower wells. Cells were starved in M199 containing 1\% FBS for $6 \mathrm{hr}$ at $37^{\circ} \mathrm{C}$, after which the HUVECs were harvested and resuspended to a final concentration of $1 \times 10^{5}$ cells $/ \mathrm{ml}$ in various concentrations of RCME diluted in M199 medium (1\% FBS). RCME was added to the cells for $30 \mathrm{~min}$ at room temperature before seeding. Subsequently, $100 \mu \mathrm{l}$ of each cell solution containing RCME was added to the upper wells. The chamber was incubated at $37^{\circ} \mathrm{C}$ for $4 \mathrm{hr}$. Cells were fixed and stained with hematoxylin and eosin (H\&E). Non-migrating cells on the upper surface of the filter were removed by wiping with a cotton swab, and chemotaxis was measured with an optical microscope $(\times 200)$ by examining the number of cells that migrated to the lower side of the filter. Eight fields of view were counted for each assay.

\section{Endothelial cell invasion assay}

The effect of RCME on HUVEC invasion was measured using a Cultrex ${ }^{\circledR}$ Cell Invasion Assay Kit (Trevigen, Gaithersburg, MD). Briefly, the membrane of the upper invasion chamber was coated with basement membrane extract (BME) to prevent migration of noninvasive cells (Albini et al., 1987). HUVECs $\left(5 \times 10^{4}\right.$ cells $)$ were then resuspended in $100 \mu \mathrm{l}$ of low-serum medium (1\% FBS) and seeded onto culture inserts. The cells were then deposited into a 24-well companion plate with $600 \mu \mathrm{l}$ of low-serum medium containing VEGF (20 ng/ml) and various concentrations of RCME. Wells containing VEGF alone served as a positive control. After incubation for 48 $\mathrm{hr}$, the media from the wells were withdrawn and the noninvasive cells on the upper surface of the membrane were removed by wiping with cotton swabs. The cells that had penetrated the BME-coated membrane and migrated onto the lower surface of the membrane were stained with H\&E and mounted onto microscope slides. Images of the invasive cells were captured at $100 \times$ magnification using an optical inverted microscope. HUVEC invasion was quantified by counting the number of cells per insert.

\section{Gelatinolytic zymography}

Gelatin zymography was used to detect the expression of matrix metalloproteinases (MMPs) in supernatant media in the presence or absence of RCME as described previously (Leber and Balkwill, 1997). Briefly, collected medium was centrifuged at $1,500 \mathrm{rpm}$ for $5 \mathrm{~min}$ at $4{ }^{\circ} \mathrm{C}$ to remove cellular debris. The amount of secreted proteins in the conditioned media was quantified by Bio-Rad protein assay dye reagent concentrate (Bio-Rad). The conditioned media containing $20 \mu \mathrm{g}$ of secreted proteins was then mixed with SDS-PAGE loading buffer in the absence of a reducing agent. Protein samples were then loaded onto $10 \%$ SDS-PAGE copolymerized with $0.2 \%$ gelatin and subjected to electrophoresis. In order to remove SDS, gels were washed twice for $30 \mathrm{~min}$ with $2.5 \%$ Triton X-100 solution, rinsed with incubation buffer $(50 \mathrm{mM}$ Tris- $\mathrm{HCl}$ buffer, $\mathrm{pH}$ 7.5 containing $10 \mathrm{mM} \mathrm{CaCl}_{2}$ plus $1 \mu \mathrm{M} \mathrm{ZnCl}_{2}$ ) and then incubated at $37^{\circ} \mathrm{C}$ for either $3 \mathrm{hr}$ or overnight. Gelatinases were identified following staining of the gel in $0.25 \%$ Coomassie Brilliant Blue R250 (Sigma) and de-staining in $7 \%$ acetic acid.

\section{In vitro capillary-like tube formation assay}

The ability of HUVECs to form network structures was tested on Matrigel basement membrane matrix (BD Biosciences, Bedford, MA) (Lee et al., 1999). Briefly, $250 \mu \mathrm{l}$ of growth factor-reduced Matrigel was pipetted into a 24well culture plate and polymerized for $30 \mathrm{~min}$ at $37^{\circ} \mathrm{C}$. 
HUVECs incubated for $6 \mathrm{hr}$ in M199 medium containing $1 \%$ FBS were harvested by trypsin treatment and suspended in M199 medium containing 1\% FBS. RCME was incubated with cells for $30 \mathrm{~min}$ at room temperature prior to plating the cells onto a layer of Matrigel at a density of 2 $\times 10^{5}$ cells per well, at which point $20 \mathrm{ng} / \mathrm{ml}$ of VEGF was added. After $20 \mathrm{hr}$, cultures were imaged $(\times 40)$. The area covered by the tube network was determined using an optical imaging technique in which pictures of the tubes were scanned in Adobe Photoshop and quantified using Image-Pro Plus (Media Cybermetics, Bethesda, MD).

\section{Ex vivo rat aortic sprouting assay}

Angiogenesis ex vivo was studied by rat aortic ring assay (Kruger et al., 2000). Briefly, a 48-well plate was first covered with Matrigel $(120 \mu \mathrm{l})$ and incubated for $30 \mathrm{~min}$ at $37^{\circ} \mathrm{C}$. Subsequently, 7-week-old Sprague-Dawley rats were sacrificed by cervical dislocation, and the thoracic aortas were dissected and cut into $1 \mathrm{~mm}$ long sections. Afterwards, aortic rings were placed into wells pre-coated with Matrigel, and then covered with another layer of Matrigel $(50 \mu \mathrm{l})$. After polymerization for $30 \mathrm{~min}$, serum-free M199 media was added to each well. VEGF with or without RCME was then added to the wells in a final volume of $600 \mu \mathrm{l}$ of human endothelial serum-free medium (Invitrogen). On day 7, cells were fixed and stained with Diff-Quick, and neovessels were imaged at $40 \times$ magnification using a Nikon eclipse TS100 inverted microscope. The angiogenic response was measured by quantifying the number of neovessels that sprouted out of the rings during the incubation period. Sprouting was measured using the following scale: $0=$ no sprouting; $1=$ migrated cells without sprouting; $2=$ isolated sprouting; $3=$ sprouting in $25 \sim 50 \%$ of the arterial ring circumference; $4=$ sprouting in $50 \sim 75 \%$ of the circumference; and $5=$ sprouting in $75 \sim 100 \%$ of the circumference. The assay was scored from 0 to 5 in a double-blinded manner, and each data point was quantified six times.

\section{Statistical analysis}

Results are presented as the mean \pm standard deviation (S.D.). Statistical analysis of the data was performed using Student's $t$-test and one-way analysis of variance (ANOVA).
Values of $P<0.05$ were considered to indicate statistically significant differences.

\section{RESULTS}

\section{Effect of RCME on HUVEC viability}

To rule out any toxic effects of RCME for evaluating angiogenesis, we first examined the viability of HUVECs after exposure to RCME. As shown in Fig. 1A, exposure to RCME for $24 \mathrm{hr}$ induced cytotoxicity in a dose-dependent manner. A significant inhibitory effect on cell viability was observed in response to RCME at concentrations $\geq 50 \mu \mathrm{g}$ / $\mathrm{ml}$. No significant cytotoxicity was observed at doses of up to $25 \mu \mathrm{g} / \mathrm{ml} \mathrm{RCME}$ during the $24 \mathrm{hr}$ cultivation period.

\section{Inhibitory effect of RCME on VEGF-induced endothelial cell proliferation}

Proliferation of endothelial cells in response to an angiogenic factor is an important step during angiogenesis (Cardenas et al., 2011). To assess the anti-angiogenic activity of RCME in vitro, the effect of RCME on VEGF-induced endothelial cell proliferation was evaluated. HUVECs were pretreated for 40 min with various concentrations of RCME before being exposed to VEGF (20 ng/ml) for $24 \mathrm{hr}$. RCME inhibited VEGF-induced proliferation, with a half maximal inhibition taking place at $10 \mu \mathrm{g} / \mathrm{ml}$ (Fig. 1B). These inhibitory effects were not due to cytotoxicity because RCME up to $25 \mu \mathrm{g} / \mathrm{ml}$ had no effect on the normal growth of HUVECs in the absence of VEGF (Fig. 1A).

\section{Effect of RCME on ERK, p38 and VEGFR2 phos- phorylation}

In order to identify the downstream signaling pathways targeted by RCME, we next examined the phosphorylation of MAPK, one of the key signaling pathway components that drive endothelial cell proliferation, migration and tube formation (Rousseau et al., 1997; Takahashi et al., 1999; Huang et al., 2004; Chrzanowska et al., 2008). While treatment with RCME inhibited VEGF-dependent phosphorylation of extracellular signal-regulated kinase 1/2 (ERK $1 / 2$ ) and p38 in a dose-dependent manner, total ERK and p38 levels were not affected (Figs. 2A and B). Next, we 
(A)

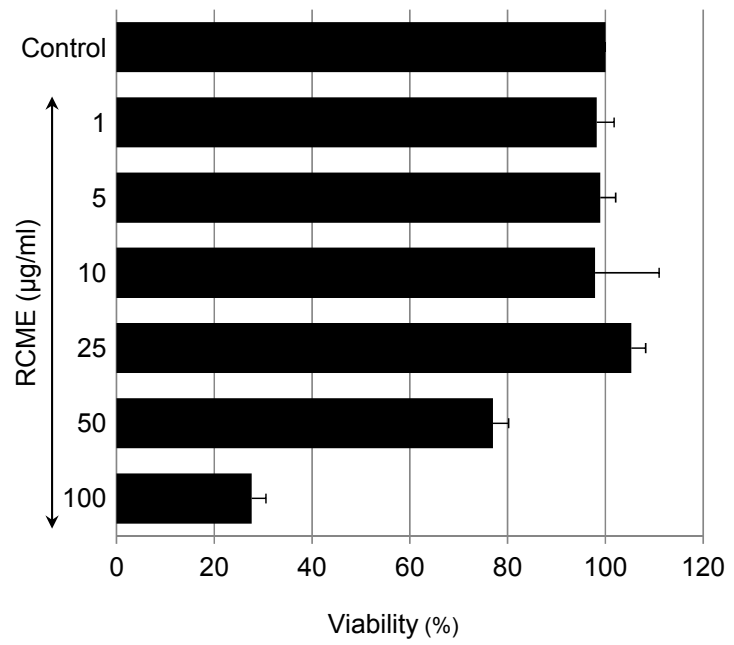

B

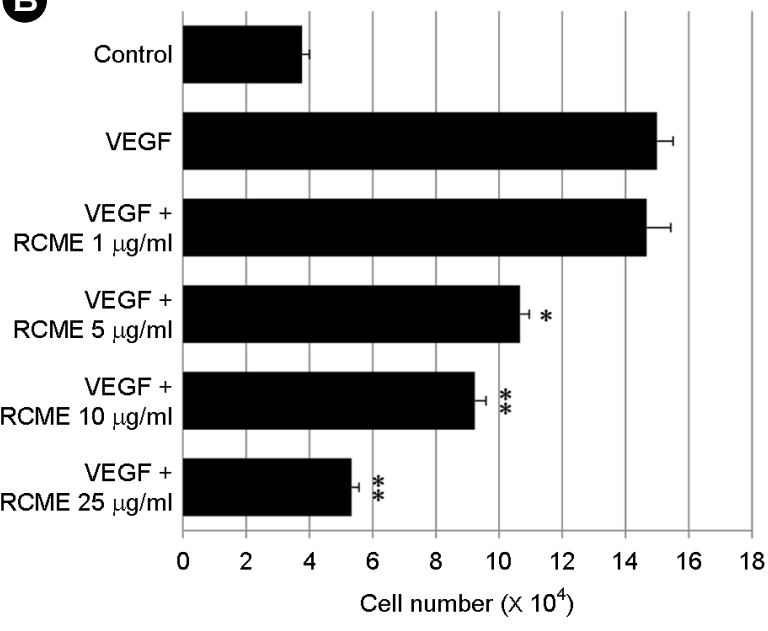

Fig. 1. Effects of RCME on cytotoxicity and proliferation of HUVECs. (A) HUVECs were incubated with various concentrations (1, $5,10,25,50$ and $100 \mu \mathrm{g} / \mathrm{ml}$ ) of RCME. After $24 \mathrm{hr}$, cytotoxicity was determined by an MTT assay. (B) HUVECs were pretreated for 40 min with various concentrations $(1,5,10$ and $25 \mu \mathrm{g} / \mathrm{ml})$ of RCME before exposure to VEGF (20 ng/ml). After $24 \mathrm{hr}$, the number of proliferating cells was quantified by microscopy. Each bar represents the average $\pm \mathrm{SE}$ of three independent experiments. $* P<0.05$ and $* * P<0.01$ versus VEGF alone.

performed Western blot analysis to evaluate the possibility that the anti-angiogenic effects of RCME were mediated through the inhibition of VEGFR2 phosphorylation. We found that VEGF-induced phosphorylation of VEGFR2 inhibited by RCME, but that VEGFR2 expression was not affected by RCME treatment itself (Fig. 2C). These results indicated that the inhibitory effect of RCME on VEGFinduced angiogenesis of HUVECs may have been due to inhibition of tyrosine phosphorylation of VEGFR2, and thus may be useful as potent angiogenesis inhibitors by inhibiting VEGFR2-mediated signaling pathways.

\section{Effect of RCME on VEGF-induced endothelial cell motility}

Migration of endothelial cells is essential for tumor angio-genesis, and thus we next examined the ability of RCME to inhibit cell motility in migration assays (Wen et al., 2008). After stimulating HUVECs with $20 \mathrm{ng} / \mathrm{ml}$ VEGF for $4 \mathrm{hr}$, a large number of cells migrated to the lower side of the filter in the Transwell Chamber. This VEGF-induced migration of endothelial cells was dose-dependently inhibited by RCME treatment (Fig. 3). Importantly, RCME alone had no significant effect on basal migration of endo- thelial cells.

Effect of RCME on VEGF-induced endothelial cell invasion and MMP expression

To form new blood vessels, migrating endothelial cells must break free and traverse from their own basement membrane (Sage, 1997). Thus, we evaluated the ability of RCME to inhibit the invasion of human endothelial cells using a Transwell culture plate. As shown in Fig. 4A, VEGF-treated cells serving as positive controls exhibited increased invasion; however, the number of invading cells in response to VEGF was significantly reduced in a dosedependent manner with RCME treatment. An essential pattern of this invasion included degradation of the basement membrane (BM). Matrix metalloproteinases (MMPs) are a family of inducible enzymes that degrade extracellular matrix (ECM) components, allowing cells to efficiently traverse the BM. Therefore, we performed gelatin zymography to examine the effect of RCME on the VEGFstimulated expression of MMP-2 and -9. Both MMP-2 and -9 can hydrolyze gelatin substrates incorporated into an SDS-PAGE gel, and gelatin hydrolysis by MMP-2 and -9 can be visualized by Coomassie Brilliant Blue R250 staining. 
(A)

\begin{tabular}{|c|c|c|c|c|c|c|c|c|c|c|}
\hline & & & & $* *$ & & & & & & \\
\hline & & & $* *$ & & & & & & & \\
\hline & & Г & & 1 & & & & & & \\
\hline VEGF & - & + & + & + & + & + & - & - & - & - \\
\hline $\begin{array}{l}\text { RCME } \\
(\mu \mathrm{g} / \mathrm{ml})\end{array}$ & - & - & 1 & 5 & 10 & 25 & 1 & 5 & 10 & 25 \\
\hline
\end{tabular}

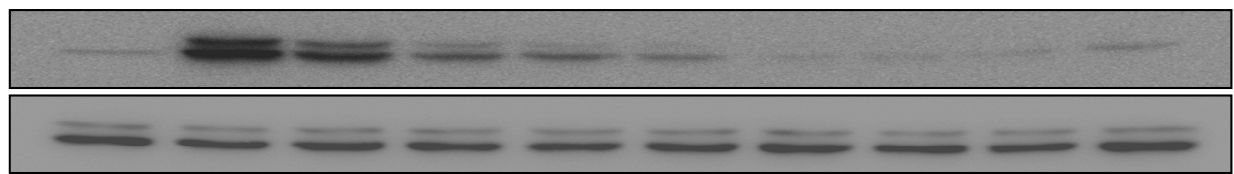

p-ERK

ERK

$\begin{array}{lllllllllll}\text { Relative density } & 1 & 10.8 & 8.1 & 3.8 & 2.4 & 1.2 & 0.7 & 0.7 & 0.7 & 0.8\end{array}$
$(\mathrm{p}-\mathrm{ERK} / \mathrm{ERK})$

B

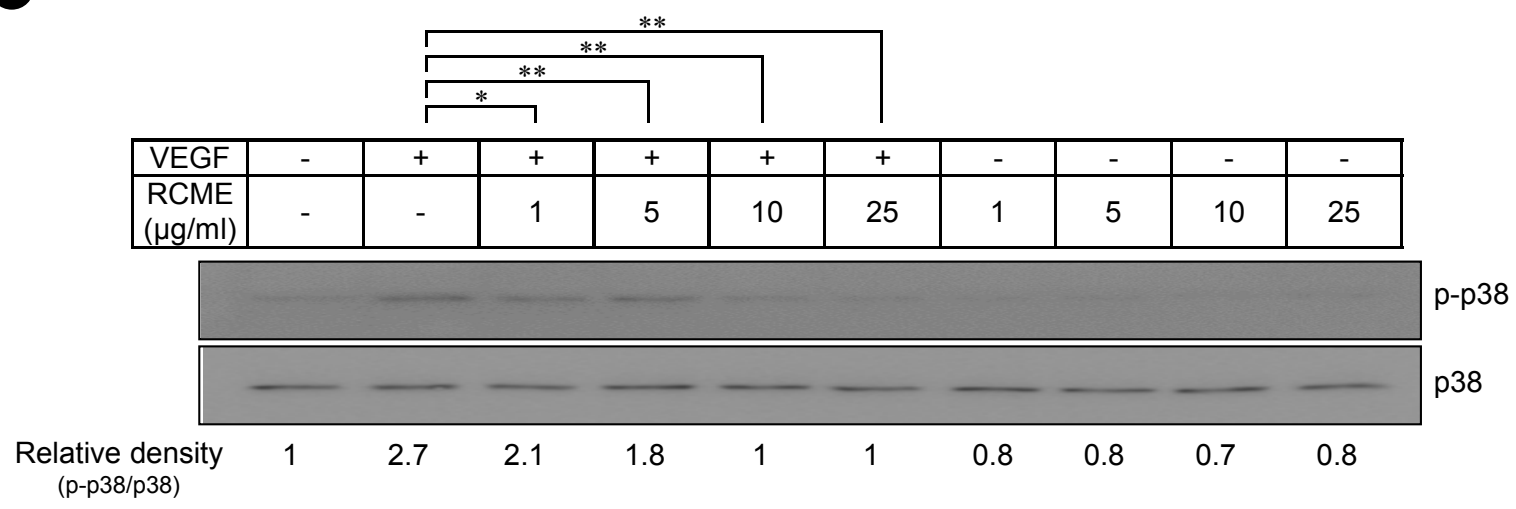

C

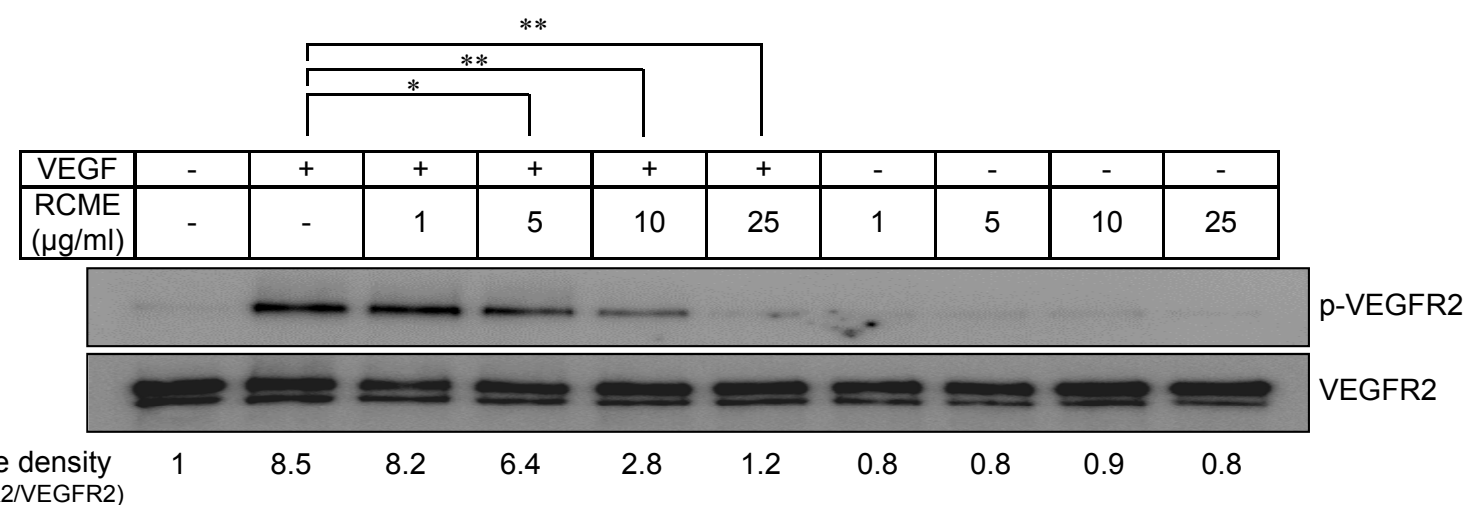

Fig. 2. RCME inhibits VEGF-induced phosphorylation of ERK, p38 and VEGFR2. HUVECs were pretreated for 40 min with various concentrations $(1,5,10$, and $25 \mu \mathrm{g} / \mathrm{ml})$ of RCME and treated with VEGF $(20 \mathrm{ng} / \mathrm{ml})$ for $10 \mathrm{~min}$. Next, cells were harvested and the levels of phosphorylated and total ERK (A), p38 (B) and VEGFR2 (C) were determined by Western blot analysis. Data are expressed as mean \pm $\mathrm{SE}(\mathrm{n}=3) . * P<0.05$ and $* * P<0.01$ versus VEGF alone.

Analysis of serum-free conditioned medium of VEGFstimulated HUVECs revealed the presence of gelatinolytic activity indicative of both MMP-2 and -9 activity. VEGF- stimulated activation of MMP-2 and -9 was inhibited by RCME treatment (Fig. 4B). In addition, we used conditioned medium of phorbol 12-myristate 13-acetate (PMA)- 
(A)

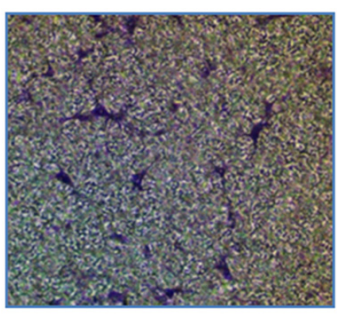

Control

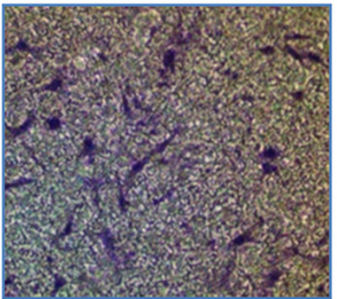

VEGF

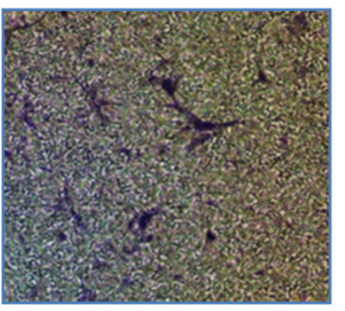

VEGF

$+\mathrm{RCME} 25 \mu \mathrm{g} / \mathrm{ml}$

B

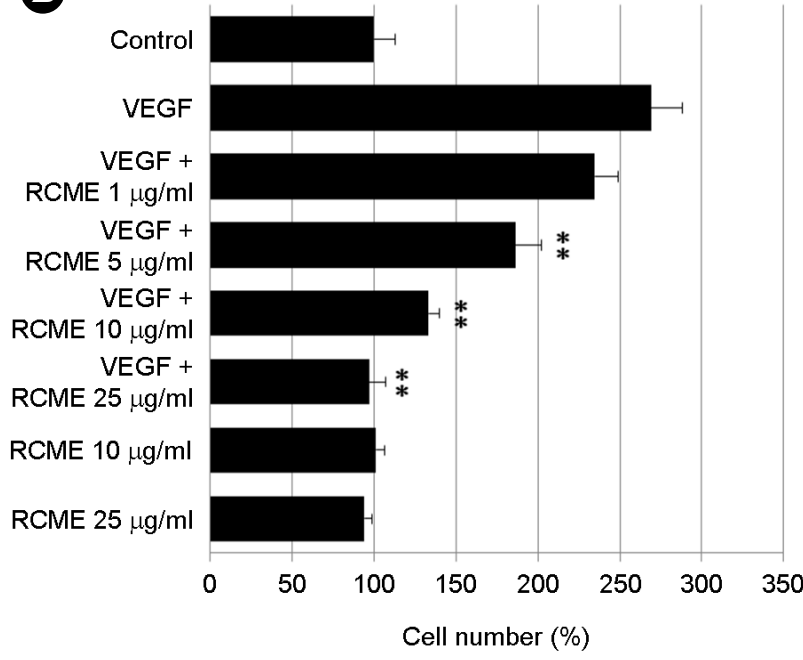

Fig. 3. RCME inhibits VEGF-induced migration of HUVECs. HUVECs were pretreated for $40 \mathrm{~min}$ with various concentrations $(1,5,10$ and $25 \mu \mathrm{g} / \mathrm{ml}$ ) of RCME before exposure to VEGF (20 ng/ml). Chemotactic migration after incubation in Transwell plates for $4 \mathrm{hr}$. Cells that migrated to the bottom of the filter were photographed (A) and counted (B) using optical microscopy. An in vitro angiogenesis assay was performed as described in the Materials and methods section. Data are expressed as mean $\pm \mathrm{SE}(\mathrm{n}=3)$. ${ }^{* *} P<0.01$ versus VEGF alone.

A

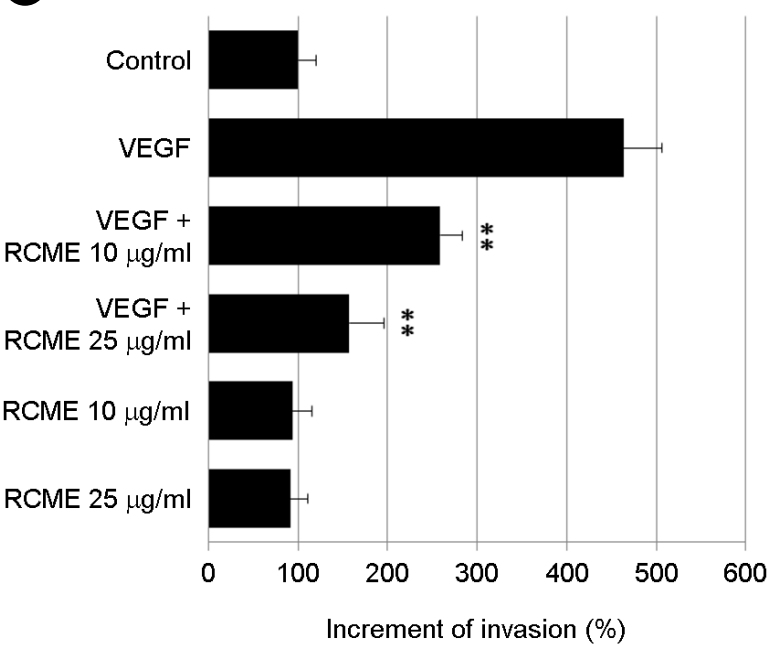

B
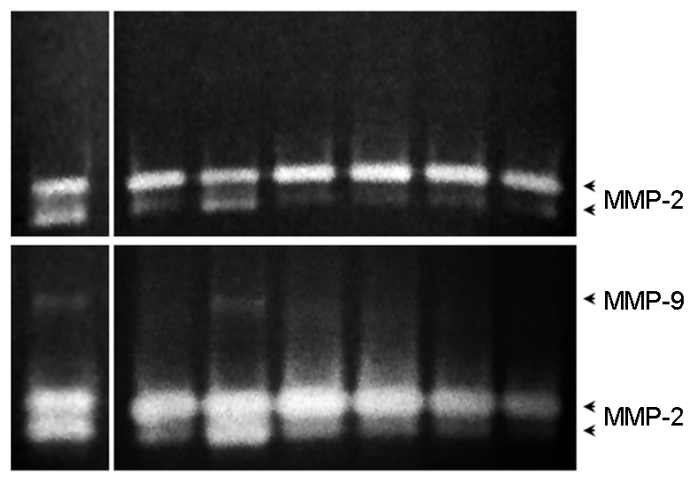

PMA

VEGF

RCME

$(\mu \mathrm{g} / \mathrm{ml})$

Fig. 4. RCME inhibits VEGF-induced invasion and MMP expression of endothelial cells. (A) Effect of RCME on HUVEC invasion using a Transwell culture plate. HUVECs were pretreated for 40 min with 10 or $25 \mu \mathrm{g} / \mathrm{ml}$ of RCME before exposure to VEGF (20 ng/ml for $16 \mathrm{hr}$ ). VEGF treatment alone served as a positive control. (B) Gelatin zymography of the culture medium of HUVECs. After pretreatment with 10 or $25 \mu \mathrm{g} / \mathrm{ml}$ of RCME for $40 \mathrm{~min}$, cells were treated with VEGF $(20 \mathrm{ng} / \mathrm{ml})$ for $12 \mathrm{hr}$. The culture media were used in gelatin-based electrophoresis, incubated at $37^{\circ} \mathrm{C}$ for either $3 \mathrm{hr}$ (upper panel) or overnight (lower panel), and stained with Coomassie Brilliant Blue R250. The culture medium from HUVECs treated with PMA (40 ng/ml for $12 \mathrm{hr}$ ) was used to distinguish between different types of MMPs. Experiments were repeated three times, and values are mean \pm SE of triplicate determinations. ${ }^{* *} P<0.01$ versus VEGF alone. 
stimulated HUVECs to distinguish between different MMPs (Hanemaaijer et al., 1993).

\section{Effect of RCME on VEGF-induced endothelial cell tube formation}

Next, to further characterize the anti-angiogenic activity of RCME, we investigated its ability to inhibit VEGFinduced tube formation by endothelial cells in Matrigel, a well-established angiogenesis assay. When HUVECs were placed on growth factor-reduced Matrigel in the presence of VEGF, we observed formation of elongated and robust tube-like structures that were organized by much larger numbers of cells than in the absence of VEGF within $20 \mathrm{hr}$. However, treatment of RCME dose-dependently reduced both the width and length of the endothelial tubes induced by VEGF (Fig. 5).

\section{Inhibition of VEGF-induced vessel sprouting ex vivo by} RCME

To verify the anti-angiogenic effect of RCME ex vivo, we employed the rat aortic ring sprouting assay (Kruger et al., 2000). The rat aortic ring sprouting assay is a widely used ex vivo anti-angiogenic model that mimics several stages of angiogenesis including vascular endothelial cell proliferation, migration and tube formation. Rat aortic rings were embedded in Matrigel and fed with medium containing different concentrations of RCME. Next, the rings were stimulated with $20 \mathrm{ng} / \mathrm{ml}$ VEGF and sprout formation was examined by microscopy. Treatment with VEGF significantly stimulated vessel outgrowth when compared to the results with medium alone. However, VEGF-induced vessel sprouting was strongly reduced by RCME treatment. This result indicated that RCME induced a dramatic decrease in microvessel outgrowth from the aortic ring in a dosedependent manner (Fig. 6).

\section{DISCUSSION}

Angiogenesis is a critical step in the development and progression of most human tumors. Therefore, interruption of angiogenesis is an important approach for tumor treatment and prevention. VEGF is a powerful angiogenic growth

\section{A}
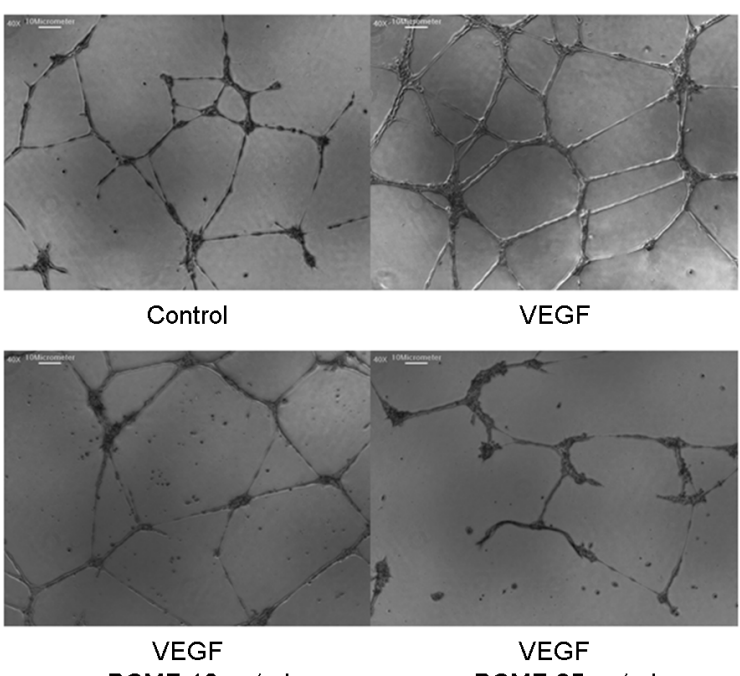

+ RCME $10 \mu \mathrm{g} / \mathrm{ml}$

+ RCME $25 \mu \mathrm{g} / \mathrm{ml}$

B

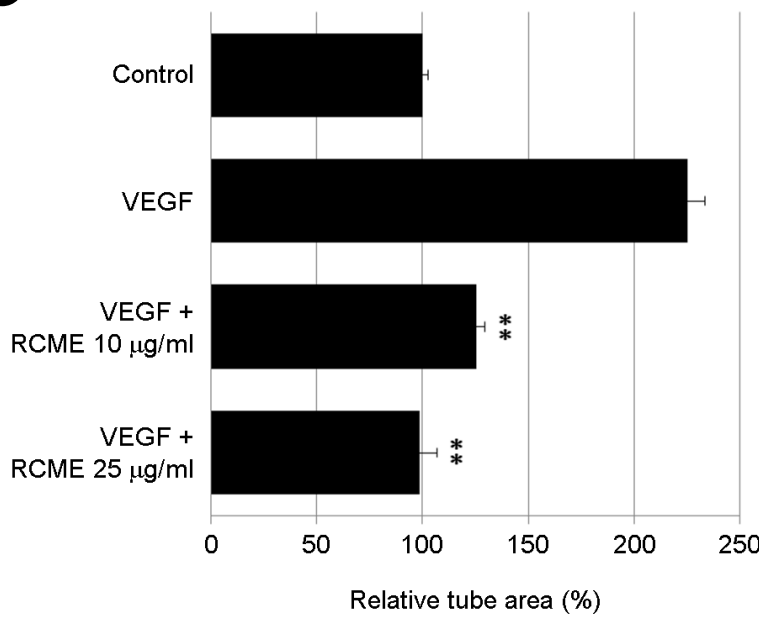

Fig. 5. RCME inhibits VEGF-induced tube formation of endothelial cells. HUVECs were pre-incubated for $40 \mathrm{~min}$ with 10 or $25 \mu \mathrm{g} / \mathrm{ml} \mathrm{RCME}$ and plated on Matrigel-coated plates at a density of $2 \times 10^{5}$ cells per well. Cells were then incubated in the presence or absence of $20 \mathrm{ng} / \mathrm{ml} \mathrm{VEGF,} \mathrm{and} \mathrm{microphotographs} \mathrm{were} \mathrm{obtained}$ after $20 \mathrm{hr}(\times 40)$. (A) Representative endothelial tubes are shown. (B) The area covered by the tube network was measured using Image-Pro Plus software. Experiments were repeated three times, and values are mean \pm SE of triplicate determinations. ${ }^{* *} P<0.01$ versus VEGF alone.

factor that has been shown to stimulate tumoral angiogenesis in both an autocrine and paracrine fashion. The specific function of VEGF is regulated primarily by two types of receptor tyrosine kinases (RTKs) of the VEGF family, namely, VEGFR1/Flt-1 and VEGFR2/KDR/Flk-1 
A

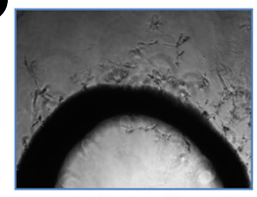

Control

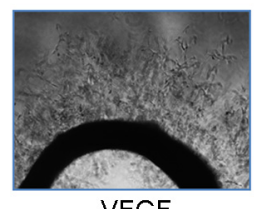

VEGF

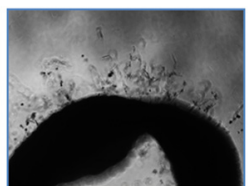

RCME $10 \mu \mathrm{g} / \mathrm{ml}$

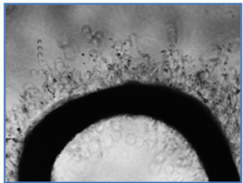

VEGF

$+\mathrm{RCME} 10 \mu \mathrm{g} / \mathrm{m}$

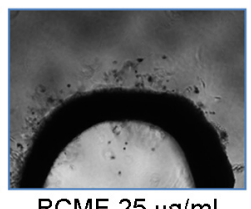

$\mathrm{RCME} 25 \mu \mathrm{g} / \mathrm{ml}$

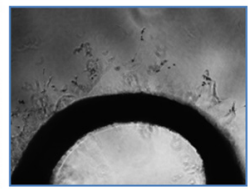

VEGF

$+\mathrm{RCME} 25 \mu \mathrm{g} / \mathrm{ml}$
B

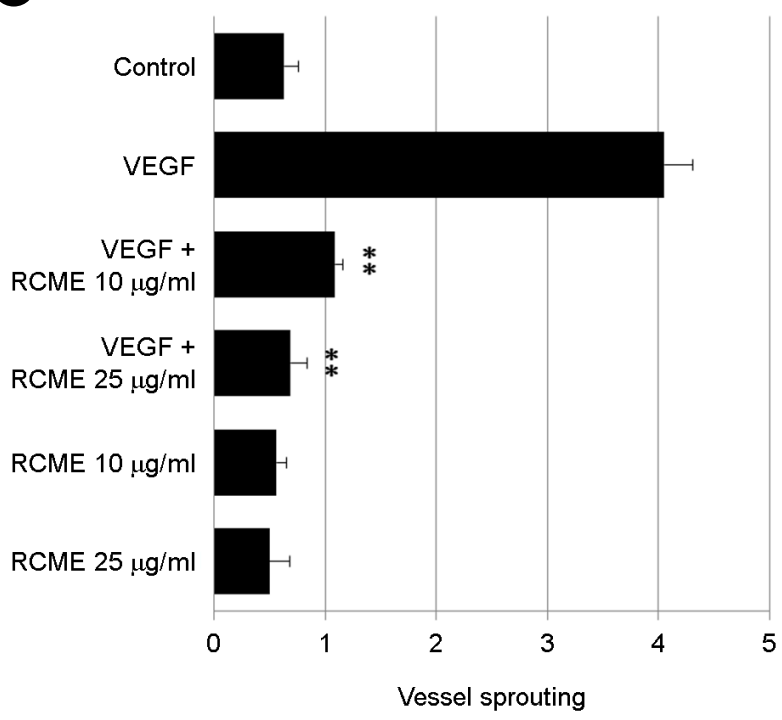

Fig. 6. RCME inhibits VEGF-induced vessel sprouting ex vivo. Aortae in Matrigel were exposed to VEGF $(20 \mathrm{ng} / \mathrm{ml})$ in the presence or absence of RCME and stained with Diff-Quick on day 7. (A) Representative aortic rings were photographed. (B) RCME blocks VEGF-vessel sprouting. The assay was scored from 0 (least positive) to 5 (most positive), and data are shown as mean \pm SE $(n=6) . * * P<0.01$ versus VEGF alone.

(Mustonen and Alitalo, 1995; Ferrara et al., 2003). KDR is the main receptor responsible for VEGF activity in both physiological and pathological vessel growth; therefore, inhibition of the VEGF signaling pathway by blocking the interaction between VEGF and its receptors is a priority target for the development of anti-tumorigenic agents. Angiogenesis inhibitors have been derived from a number of sources, including cleaved proteins, monoclonal antibodies and natural products (Kabbinavar et al., 2005; Agarwal et al., 2006; Lee et al., 2007). The use of herbal products is becoming popular as one of the promising strategies in tumor treatment. Such herbal compounds are often regarded as alternative medicine, with the claim that because of their "natural" origin they are inherently safe and have no side effects. Many bioactive natural compounds, also known as nutraceuticals, have recently been tested for potential clinical applications (Dulak, 2005). Indeed, one of the first isolated anti-angiogenic compounds was a phytochemical (Yance and Sagar, 2006). It is also possible that components of other plants, including the constituents of local medicinal herbs such as Rubus coreanus Miquel, may find application for the modulation of angiogenesis. In the present study, we demonstrated the anti-angiogenic activity of RCME using both in vitro and ex vivo models. Angiogenesis depends on a complex array of cellular activities such as extracellular matrix degradation, proliferation and migration of endothelial cells and morphological differentiation of endothelial cells to form tubes (Bussolino et al., 1997). On the cellular level, although cell viability was not affected by RCME in this study, RCME almost completely suppressed the stimulatory effect of VEGF on endothelial cell proliferation (Fig. 1), migration (Fig. 3) and tube formation (Fig. 5).

The binding of VEGF to VEGFR2 brought forth the VEGFR2 phosphorylation at Ser1175 site, a reliable marker for its activity, which in turn activated the signaling pathways of ERK1/2 and p38 MAPK (Stoclet et al., 2004; Kim et al., 2006; Lu et al., 2008). The activation of ERK and p38 MAP kinase plays an important role in endothelial cell proliferation and migration (Rousseau et al., 1997; Chrzanowska-Wodnicka et al., 2008; Matsunaga et al., 2008). In addition, the results of the present study showed that RCME inhibited phosphorylation of VEGFR2, resulting in downregulation of ERK and p38 MAP kinase phosphorylation in response to VEGF in HUVECs (Fig. 2). Our results also demonstrated that RCME inhibited VEGFinduced angiogenesis by inhibiting VEGFR2 phosphorylation. However, this finding requires further study to understand whether RCME inhibits interaction of VEGFKDR either directly or indirectly or through other pathways. In addition to proliferation, migration, and tube formation, endothelial cell invasion is also essential to the angiogenic 
process. Vascular growth requires degradation of both the basement membrane surrounding the endothelial cells and proteolysis of the extracellular matrix of the connective tissue and requires the assembly of endothelial cells into vessel tubes. MMP-2 and MMP-9 are key enzymes involved in the migration and invasion of endothelial cells and tumor cells (Oppenheim and Fujiwara, 1996; Van Moorselaar and Voest, 2002). We found that RCME strongly reduced the number of invading endothelial cells and downregulated the expression of MMP-2 and MMP-9 (Fig. 4). Similarly, when added to rat aorta rings that had been maintained in a three-dimensional Matrigel culture to allow for sprouting of new vessels, RCME remarkably suppressed in response to VEGF (Fig. 6). This ex vivo anti-angiogenic activity may be explained by the inhibitory effect of RCME on the proliferation, migration, invasion, and tube formation of endothelial cells in response to VEGF. Thus, RCME inhibits VEGF-induced angiogenesis both in vitro and ex vivo.

Collectively, our data provide the first demonstration that RCME contains strong anti-angiogenic activity, which has been detected using the in vitro and ex vivo models of angiogenesis assay. This result provides additional pharmacological information regarding the therapeutic efficacy of RCME, which should be considered as a novel candidate for the development of a new anti-angiogenic drugs targeting the VEGF signaling pathway.

\section{Acknowledgements}

This research was supported by the Leading Foreign Research Institute Recruitment Program through the National Research Foundation of Korea (NRF) funded by the Ministry of Science, ICT \& Future Planning (2010-00757).

\section{REFERENCES}

Agarwal R, Agarwal C, Ichikawa H, Singh RP, Aggarwal BB. Anticancer potential of silymarin: from bench to bed side. Anticancer Res. 2006. 26: 4457-4498.

Albini A, Iwamoto Y, Kleinman HK, Martin GR, Aaronson SA, Kozlowski JM, McEwan RN. A rapid in vitro assay for quantitating the invasive potential of tumor cells. Cancer Res. 1987. 47: 3239-3245.
Balbay MD, Pettaway CA, Kuniyasu H, Inoue K, Ramirez E, Li E, Fidler IJ, Dinney CP. Highly metastatic human prostate cancer growing within the prostate of athymic mice overexpresses vascular endothelial growth factor. Clin Cancer Res. 1999. 5: 783-789.

Bussolino F, Mantovani A, Persico G. Molecular mechanisms of blood vessel formation. Trends Biochem Sci. 1997. 22: 251 $-256$.

Cardenas C, Quesada AR, Medina MA. Anti-angiogenic and anti-inflammatory properties of kahweol, a coffee diterpene. PLoS One. 2011. 6: e23407.

Carmeliet P. Angiogenesis in health and disease. Nat Med. 2003. 9: 653-660.

Chrzanowska-Wodnicka M, Kraus AE, Gale D, White GC, Vansluys J. Defective angiogenesis, endothelial migration, proliferation, and MAPK signaling in Rap1b-deficient mice. Blood. 2008. 111: 2647-2656.

Droller MJ. Vascular endothelial growth factor is a predictor of relapse and stage progression in superficial bladder cancer. J Urol. 1998. 160: 1932.

Dulak J, Jozkowicz A. Regulation of vascular endothelial growth factor synthesis by nitric oxide: facts and controversies. Antioxid Redox Signal. 2003. 5: 123-132.

Dulak J. Nutraceuticals as anti-angiogenic agents: hopes and reality. J Physiol Pharmacol. 2005. 56: (suppl.) 51-67.

Erdemoglu N, Kupeli E, Yesilada E. Anti-inflammatory and antinociceptive activity assessment of plants used as remedy in Turkish folk medicine. J Ethnopharmacol. 2003. 89: 123 -129 .

Ferrara N, Gerber HP, LeCouter J. The biology of VEGF and its receptors. Nat Med. 2003. 9: 669-676.

Folkman J. Angiogenesis in cancer, vascular, rheumatoid and other disease. Nat Med. 1995. 1: 27-31.

Folkman J. Angiogenesis. Annu Rev Med. 2006. 57: 1-18.

Hanahan D, Folkman J. Patterns and emerging mechanisms of the angiogenic switch during tumorigenesis. Cell. 1996. 86: 354 -364 .

Hanemaaijer R, Koolwijk P, Le Clercq L, De Vree WJ, Van Hinsbergh VW. Regulation of matrix metalloproteinase expression in human vein and microvascular endothelial cells. Effects of tumour necrosis factor alpha, interleukin 1 and phorbol ester. Biochem J. 1993. 296: 803-809.

Huang C, Jacobson K, Schaller MD. MAP kinases and cell migration. J Cell Sci. 2004. 117: 4619-4628. 
Kabbinavar FF, Hambleton J, Mass RD, Hurwiz HI, Bergsland E, Sarkar S. Combined analysis of efficacy: the addition of bevacizumab to fluorouracil/leucovorin improves survival for patients with metastatic colorectal cancer. J Clin Oncol. 2005. 23: 3706-3712.

Kim EH, Na HK, Surh YJ. Upregulation of VEGF by 15-deoxyDelta12,14-prostaglandin J2 via heme oxygenase-1 and ERK1/2 signaling in MCF-7 cells. Ann N Y Acad Sci. 2006. 1090: 375-384.

Kim Y, Kim J, Lee SM, Lee HA, Park S, Kim Y, Kim JH. Chemopreventive effects of Rubus coreanus Miquel on prostate cancer. Biosci Biotechnol Biochem. 2012. 76: 737-744.

Kitamura M, Toi M, Arai K, Iwasaki Y, Suzuki H, Matsuo K. Concerntarations of vascular endothelial growth factor in the sera of gastric cancer patients. Oncol Rep. 1998. 5: 1419-1424.

Ko SH, Choi SW, Ye SK, Yoo SH, Kim HS, Chung MH. Comparison of anti-oxidant activities of seventy herbs that have been used in Korean traditional medicine. Nutr Res Pract. 2008. 2: 143-151.

Kruger EA, Duray PH, Tsokos MG, Venzon DJ, Libutti SK, Dixon SC, Rudek MA, Pluda J, Allegra C, Figg WD. Endostatin inhibits microvessel formation in the ex vivo rat aortic ring angiogenesis assay. Biochem Biophys Res Commun. 2000. 268: 183-191.

Kurebayashi J, Otsuki T, Kunisue H, Mikami Y, Tanaka K, Yamamoto S, Sonoo H. Expression of vascular endothelial growth factor (VEGF) family members in breast cancer. Jpn J Cancer Res. 1999. 90: 977-981.

Leber TM, Balkwill FR. Zymography: a single-step staining method for quantitation of proteolytic activity on substrate gels. Anal Biochem. 1997. 249: 24-28.

Lee JE, Park EK, Lee JE, Auh JH, Choi HK, Lee JH, Cho SM, Kim JH, Kim YR. Effects of a Rubus coreanus Miquel supplement on plasma antioxidant capacity in healthy Korean men. Nutr Res Pract. 2011. 5: 429-434.

Lee OH, Kim YM, Lee YM, Moon EJ, Lee DJ, Kim JH, Kim KW, Kwon YG. Sphingosine 1-phosphate induces angiogenesis: its angiogenic action and signaling mechanism in human umbilical vein endothelial cells. Biochem Biophys Res Commun. 1999. 264: 743-750.

Lee SY, Chung SM. Neovastat (AE-941) inhibits the airway inflammation via VEGF and HIF-2 alpha suppression. Vascul Pharmacol. 2007. 47: 313-318.

Lin JK, Chen YC, Huang YT, Lin-Shiau SY. Suppression of protein kinase $\mathrm{C}$ and nuclear oncogene expression as possible molecular mechanisms of cancer chemoprevention by apigenin and curcumin. J Cell Biochem. 1997. 28/29: 39-48.

Lu N, Gao Y, Ling Y, Chen Y, Yang Y, Gu HY, Qi Q, Liu W, Wang XT, You QD, Guo QL. Wogonin suppresses tumor growth in vivo and VEGF-induced angiogenesis through inhibiting tyrosine phosphorylation of VEGFR2. Life Sci. 2008. 82: 956-963.

Matsunaga N, Shimazawa M, Otsubo K, Hara H. Phosphatidylinositol inhibits vascular endothelial growth factor-A--induced migration of human umbilical vein endothelial cells. J Pharmacol Sci. 2008. 106: 128-135.

Mustonen T, Alitalo K. Endothelial receptor tyrosine kinases involved in angiogenesis. J Cell Biol. 1995. 129: 895-898.

Nam JH, Jung HJ, Choi J, Lee KT, Park HJ. The anti-gastropathic and anti-rheumatic effect of niga-ichigoside F1 and 23hydroxytormentic acid isolated from the unripe fruits of Rubus coreanus in a rat model. Biol Pharm Bull. 2006. 29: 967-970.

Oppenheim J, Fujiwara H. The role of cytokines in cancer. Cytokine Growth Factor Rev. 1996. 7: 279-288.

Rao CV, Rivenson A, Simi B, Reddy BS. Chemoprevention of colon cancer by dietary curcumin. Ann N Y Acad Sci. 1995. 768: 201-204

Risau W. Differentiation of endothelium. FASEB J. 1995. 9: 926 $-933$.

Rousseau S, Houle F, Landry J, Huot J. p38 MAP kinase activation by vascular endothelial growth factor mediates actin reorganization and cell migration in human endothelial cells. Oncogene 1997. 15: 2169-2177.

Sage EH. Pieces of eight: bioactive fragments of extracellular proteins as regulators of angiogenesis. Trends Cell Biol. 1997. 7: 182-186.

Shaheen RM, Davis DW, Liu W, Zebrowski BK, Wilson MR, Bucana CD, McConkey DJ, McMahon G, Ellis LM. Antiangiogenic therapy targeting the tyrosine kinase receptor for vascular endothelial growth factor receptor inhibits the growth of colon cancer liver metastasis and incuces tumor and endothelial cell apoptosis. Cancer Res. 1999. 59: 5412-5416.

Stoclet JC, Chataigneau T, Ndiaya M, Oak MH, El Bedoui J, Chataiqneau M, Schini-Kerth VB. Vascular protection by dietary polyphenols. Eur J Pharmacol. 2004. 500: 299-313.

Takahashi T, Ueno H, Shibuya M. VEGF activates protein kinase C-dependent, but Ras-independent Raf-MEK-MAP kinase pathway for DNA synthesis in primary endothelial cells Oncogene. 1999. 18: 2221-2230.

Van Moorselaar RJ, Voest EE. Angiogenesis in prostate cancer: its 
role in disease progression and possible therapeutic approaches. Mol Cell Endocrinol. 2002. 197: 239-250.

Wen W, Lu J, Zhang K, Chen S. Grape seed extract inhibits angiogenesis via suppression of the vascular endothelial growth factor receptor signaling pathway. Cancer Prev Res (Phila). 2008. 1: 554-561.

Yance DR, Sagar SM. Targeting angiogenesis with integrative cancer therapies. Integr Cancer Ther. 2006. 5: 9-29.

Yoshiji H, Kuriyama S, Hicklin DJ, Huber J, Yoshii J, Miyamoto Y, Kawata M, Ikenaka Y, Nakatani T, Tsujinoue H, Fukui H. $\mathrm{KDR} / \mathrm{Flk}-1$ is a major regulator of vascular endothelial growth factor-induced tumor development and angiogenesis in murine hepatocellular carcinoma cells. Hepatology. 1999. 30: $1179-1186$ 